\title{
Sclerostin Levels Predict Cardiovascular Mortality in Long-Term Hemodialysis Patients: A Prospective Observational Cohort Study
}

\author{
M. KALOUSOVÁ ${ }^{1}$, S. DUSILOVÁ-SULKOVÁ ${ }^{2}$, A. A. KUBĚNA ${ }^{1}$, O. ZAKIYANOV ${ }^{3}$, \\ V. TESAR $\check{R}^{3}$, T. ZIMA ${ }^{1}$
}

${ }^{1}$ Institute of Medical Biochemistry and Laboratory Diagnostics, First Faculty of Medicine, Charles University and General University Hospital in Prague, Prague, Czech Republic, ${ }^{2}$ Hemodialysis Centre, University Hospital Hradec Králové and Academic Department of Internal Medicine, Charles University, Medical Faculty in Hradec Králové, Hradec Králové, Czech Republic, ${ }^{3}$ Department of Nephrology, First Faculty of Medicine, Charles University and General University Hospital in Prague, Prague, Czech Republic

Received September 21, 2018

Accepted April 1, 2019

Epub Ahead of Print June 6, 2019

\section{Summary}

Sclerostin is a protein which is involved in bone metabolism and probably also in vessel wall function. This prospective observational cohort study evaluated the prognostic significance of sclerostin in hemodialysis (HD) patients. In total, $106 \mathrm{HD}$ patients and 25 healthy controls participated in the study. HD patients were prospectively followed up for five years. Sclerostin was measured in serum using standard ELISA kits by Biomedica. Sclerostin concentrations in serum were higher in HD patients compared to the controls $(89.2 \pm 40.3 \mathrm{pmol} / \mathrm{l}$ vs. $32.8 \pm 13.0 \mathrm{pmol} / \mathrm{l}, \mathrm{p}<0.001)$. Sclerostin levels were significant for cardiovascular mortality but not for overall mortality and mortality due to infection. A higher cardiovascular risk was connected to sclerostin concentrations above the median (>84 pmol/l), HR (95\% CI): 2.577 (1.0002-10.207), p=0.04. When sclerostin was evaluated together with residual diuresis in Kaplan-Meier analysis the worst prognosis due to cardiovascular events was observed in the group with high sclerostin and zero residual diuresis compared to all other patients $(p=0.007)$. In summary, serum sclerostin levels in HD patients were increased when compared to healthy subjects. High sclerostin levels were demonstrated as a risk factor for cardiovascular mortality. Further studies are required to clarify the pathophysiological mechanisms of sclerostin action in patients with renal failure before therapeutic measures can be established.

\section{Key words}

Cardiovascular • Hemodialysis • Mortality • Outcome • Sclerostin

\section{Corresponding author}

M. Kalousová, Institute of Medical Biochemistry and Laboratory Diagnostics, First Faculty of Medicine, Charles University and General University Hospital in Prague, Kateřinská 32, 12108 Prague 2, Czech Republic. E-mail: marta.kalousova@lf1.cuni.cz

\section{Introduction}

Sclerostin is a product of the SOST gene located on chromosome 17q12-21 (Balemans et al. 2001, Brunkow et al. 2001). It is a glycoprotein with a molecular weight of $22 \mathrm{kDa}$. This protein is expressed in osteocytes buried in the bone mineralized matrix and influences bone metabolism (Poole et al. 2005). In addition, osteocytes develop a wide web with activated sensors capable of identifying markers in blood and secrete hormones including sclerostin and fibroblast growth factor 23 (FGF23) which influence distant organs (Dallas et al. 2013). It inhibits osteoblastogenesis and contributes to the development of osteoporosis. Sclerostin acts as an inhibitor of the $\mathrm{Wnt} / \beta$-cathenin pathway, which is also important in blood vessels (van Bezooijen et al. 2007). Some of the sclerostin is secreted into general circulation where sclerostin can supress the change of vascular smooth muscle cells into osteoblast-like cells (Ott 2015).

Sclerostin was first described in 2001 (Balemans et al. 2001, Brunkow et al. 2001) and till now (September 
13, 2018) there are more than 1570 records for key words "sclerostin" or "SOST" in the medical database Medline, 235 of which are from 2017 and the first half of 2018. This profound interest and research is focused on the possible roles of sclerostin in a number of disease states. Decreased or lacking sclerostin was documented in sclerosteosis (Balemans et al. 2001, Brunkow et al. 2001) and van Buchem disease (Balemans et al. 2002), while its increase occurs with age (Mödder et al. 2011), physical inactivity (Amrein et al. 2012) and also in chronic kidney disease (Pelletier et al. 2013). Sclerostin is of significance in bone diseases mainly in osteoporosis where this molecule is a causal player (Cosman et al. 2016), but also in Paget disease, multiple myeloma or bone metastases (Terpos et al. 2012, Yavropoulou et al. 2012).

Special area of sclerostin significance are chronic kidney disease (CKD), mineral bone disease (MBD) and possibly vascular calcifications in patients with CKD (Cejka et al. 2011, Thambiah et al. 2012, Pelletier et al. 2015, Brandenburg et al. 2016). In CKD patients, serum sclerostin is elevated and may be produced ectopically in calcified vascular smooth muscle cells and calcified aortic valves (Zhu et al. 2011, Brandenburg et al. 2013). Whether this process is a sign of the final transformation of the vascular smooth muscle cells or a defensive mechanism is not well understood.

Sclerostin correlates negatively with parathormone (PTH) levels as documented in all the studies focused on sclerostin and PTH and is related to bone density. However, its relationship to the prognosis of CKD patients, mainly patients with end stage renal disease treated with long-term hemodialysis (HD), is ambiguous according to currently available studies (Zeng et al. 2018). Some researchers reported a positive correlation, whereas others suggested none or a negative correlation (Zeng et al. 2018).

The aim of the present study was to evaluate the prognostic significance of sclerostin in our cohort of HD patients during long-term follow-up.

\section{Methods}

\section{Study design and subjects}

This is a prospective observational cohort study performed in 2 dialysis centers in University hospitals in the Czech Republic. The study group consisted of 106 long-term HD patients (64 men and 42 women, mean age $61 \pm 14$ years). In total, 111 patients were assessed for eligibility in this study. Four patients were excluded as three were not in a stable clinical status at the beginning of the study, one patient refused to participate, and for another patient there was inusufficient material available for the analysis of sclerostin. All of these factors lead to the 106 patients participating in the present study. The control group for the comparison of sclerostin concentrations consisted of 25 healthy subjects (16 men and 9 women, mean age $48 \pm 11$ years). One part of the group of HD patients and controls has already been presented in our previous reports (Kalousová et al. 2014, Kalousova et al. 2015, Kalousová et al. 2017) The study was performed in adherence to the principles of the Helsinki Declaration and approved by the Ethical Committee. All participants gave informed consent prior to entering the study.

The causes of renal failure in our HD patients were as follows: diabetic nephropathy (26.4\%), hypertensive nephropathy (4.7\%), interstitial nephritis (20.75\%), glomerulonephritis (20.75\%), polycystic kidney disease $(14.2 \%)$ and multifactorial or unknown (13.2\%). Residual diuresis ranged from 0 to $2500 \mathrm{ml} /$ 24 hours. Of the patients, 53 were anuric, while the remaining 53 patients had median residual diuresis $1200 \mathrm{ml} / 24$ hours. The majority of the patients had 4-hour dialysis session three times a week and polysulphone or modified cellulosic membranes were used at the beginning of the study. The duration of dialysis treatment was 26.5 months (median, range 1-359 months). $40.6 \%$ of patients had diabetes, $58.5 \%$ dyslipidemia and almost all patients had (94.3\%) hypertension. Cardiovascular disease was recorded in the personal history in $34 \%$ (acute myocardial infarction in $15.1 \%$ ), cerebrovascular diseases in $3.8 \%$ and peripheral vascular disease in $13.2 \%$. Smoking was recorded in $15.1 \%$ of HD patients. The parameters of calcium phosphate metabolism of nearly the same cohort were presented in our previous study (Kalousova et al. 2015). The results of the routine baseline laboratory examinations are provided in Table 1.

The HD patients were treated with standard medication as recommended, which then changed during the follow up as appropriate (at the beginning of the study antihypertensive drugs in $59.4 \%$, diuretic drugs in $49.1 \%$, statins in $47.6 \%$, aspirin or other antiplatelet drugs in $17.6 \%$, iron, erythropoiesis stimulating agents (ESA), phosphate binders and vitamin D and its analogs.

The HD patients were prospectively followed up for five years or until death (April 2009 - April 2014). The causes of death were recorded and finally classified 
Table 1. The results of the laboratory examinations of hemodialysis patients and healthy controls.

\begin{tabular}{|c|c|c|c|}
\hline Parameter & HD patients & Controls & HD vs. controls - p value \\
\hline Number of patients (men/women) & $106(64 / 42)$ & $25(16 / 9)$ & \\
\hline Age (years) & $61 \pm 14$ & $48 \pm 11$ & $<0.001$ \\
\hline$B M I\left(\mathrm{~kg} / \mathrm{m}^{2}\right)$ & $27.0 \pm 5.3$ & $26.2 \pm 4.2$ & 0.4 , n.s. \\
\hline Hemoglobin $(g / l)$ & $111.8 \pm 10.7$ & $143.3 \pm 8.9$ & $<0.001$ \\
\hline Leukocytes $\left(x 10^{9} / l\right)$ & $7.4 \pm 2.2$ & $6.1 \pm 1.5$ & 0.01 \\
\hline Creatinine $(\mu \mathrm{mol} / \mathrm{l})$ & $778 \pm 218$ & $91 \pm 12$ & $<0.001$ \\
\hline Urea $(\mathrm{mmol} / \mathrm{l})$ & $23.0 \pm 6.7$ & $5.6 \pm 1.8$ & $<0.001$ \\
\hline Calcium (mmol/l) & $2.2 \pm 0.2$ & $2.3 \pm 0.1$ & $<0.001$ \\
\hline Phosphate (mmol/l) & $1.9 \pm 0.6$ & $1.3 \pm 0.2$ & $<0.001$ \\
\hline Alkaline phosphatase ( $\mu k a t / l)$ & $1.5 \pm 0.9$ & $0.8 \pm 0.2$ & $<0.001$ \\
\hline $25-\mathrm{OH}$ vitamin $\mathrm{D}_{3}(\mathrm{ng} / \mathrm{ml})$ & $18.0 \pm 15.6$ & $48.7 \pm 18.3$ & $<0.001$ \\
\hline$V D B P(\mu g / m l)$ & $213 \pm 70.9$ & $222 \pm 87.7$ & $<0.001$ \\
\hline Parathyroid hormone (pmol/l) & $34.7 \pm 35.7$ & $3.7 \pm 1.5$ & $<0.001$ \\
\hline Albumin $(g / l)$ & $40.8 \pm 3.5$ & $47.3 \pm 3.2$ & $<0.001$ \\
\hline Cholesterol (mmol/l) & $4.4 \pm 1.0$ & $5.3 \pm 1.0$ & 0.001 \\
\hline HDL cholesterol ( $\mathrm{mmol} / \mathrm{l})$ & $1.1 \pm 0.3$ & $1.5 \pm 0.5$ & $<0.001$ \\
\hline LDL cholesterol (mmol/l) & $2.4 \pm 0.9$ & $3.0 \pm 0.8$ & 0.001 \\
\hline Triacylglycerols (mmol/l) & $2.1 \pm 1.1$ & $1.7 \pm 0.9$ & 0.1, n.s. \\
\hline$C R P(m g / l)$ & $8.5 \pm 12.3$ & $6.1 \pm 3.0$ & 0.8, n.s. \\
\hline
\end{tabular}

Data are expressed as mean \pm SD (standard deviation). BMI, body mass index, CRP, C-reactive protein, HD, hemodialysis, HDL, high density lipoprotein, LDL, low density lipoprotein, VDBP, vitamin D binding protein, n.s., not significant.

based upon the patients' history as cardiovascular, infection, tumor or other. Almost half of the patients (52 patients, $49.1 \%$ ) died during the follow up. In 20 of those patients (i.e. $38.5 \%$ ) the causes of death were cardiovascular, in 18 patients (i.e. $34.6 \%$ ) they were caused by infection, in 4 patients $(7.7 \%)$ tumor and in 10 patients $(20 \%)$ the causes were other or unknown. 28 patients received a kidney transplant, 4 of which subsequently died during the follow-up.

\section{Laboratory analyses}

Blood samples in HD patients were collected after a long interdialysis interval. They were retrieved from the inserted dialysis needle prior to the administration of heparin, just before the beginning of the dialysis session. In the control group blood was taken after overnight fasting. The blood was standardly centrifuged for $10 \mathrm{~min}$ at $3000 \mathrm{rpm}$ (rotations per minute) and routine biochemical parameters were measured in the fresh samples. The serum for special analyses was stored at $-80{ }^{\circ} \mathrm{C}$.

Vitamin D in the plasma was measured using high performance liquid chromatography. The vitamin D binding protein was assessed using a standard enzyme linked immunosorbent assay (ELISA) kit (Quantikine, RD Systems, USA) according to the manufacturer's protocol. The parathyroid hormone (PTH) levels (second generation test) were determined using ECLIA (Electrochemiluminescence, Modular Roche, Germany). Details of the specific biochemical measurements are described in our previous study (Kalousova et al. 2015).

Sclerostin was measured in the serum using the ELISA kit (Biomedica, Austria) according to the manufacturer's protocol and all samples were analyzed in one laboratory. The results are expressed in pmol/1 $(1 \mathrm{pg} / \mathrm{ml}=0.044 \mathrm{pmol} / \mathrm{l})$. Routine laboratory parameters were assessed using standard laboratory methods on automated analyzers.

\section{Statistical analysis}

Statistical softwares SPSS v.16 (SPSS Inc., Chicago, IL, USA, www.spss.com) and Wolfram Mathematica 11.2 were used for statistical analysis.

The results are shown as mean $\pm \mathrm{SD}$ (standard deviation). The Mann-Whitney U-test was used for comparison between HD patients and controls. 
Comparison of sclerostin between HD patients and healthy controls was further performed using the general linear model with adjustment for age after bootstrap correction of non-normality. Assessment of the relationship between parameters was performed using Kendall's tau correlation coefficient.

The significance of sclerostin for overall mortality, cardiovascular mortality and mortality due to infection were tested. Kaplan-Meier analysis was used to construct real survival curves and hazard functions for hemodialysis patients based on sclerostin concentrations (below and above the median). The curves were compared using the log-rank test. The hazard ratios (relative risks of mortality, HR) of appropriate $95 \%$ confidence intervals (CI) for each group of patients were calculated using the Cox proportional hazard model.

All results were considered statistically significant at $\mathrm{p}<0.05$.
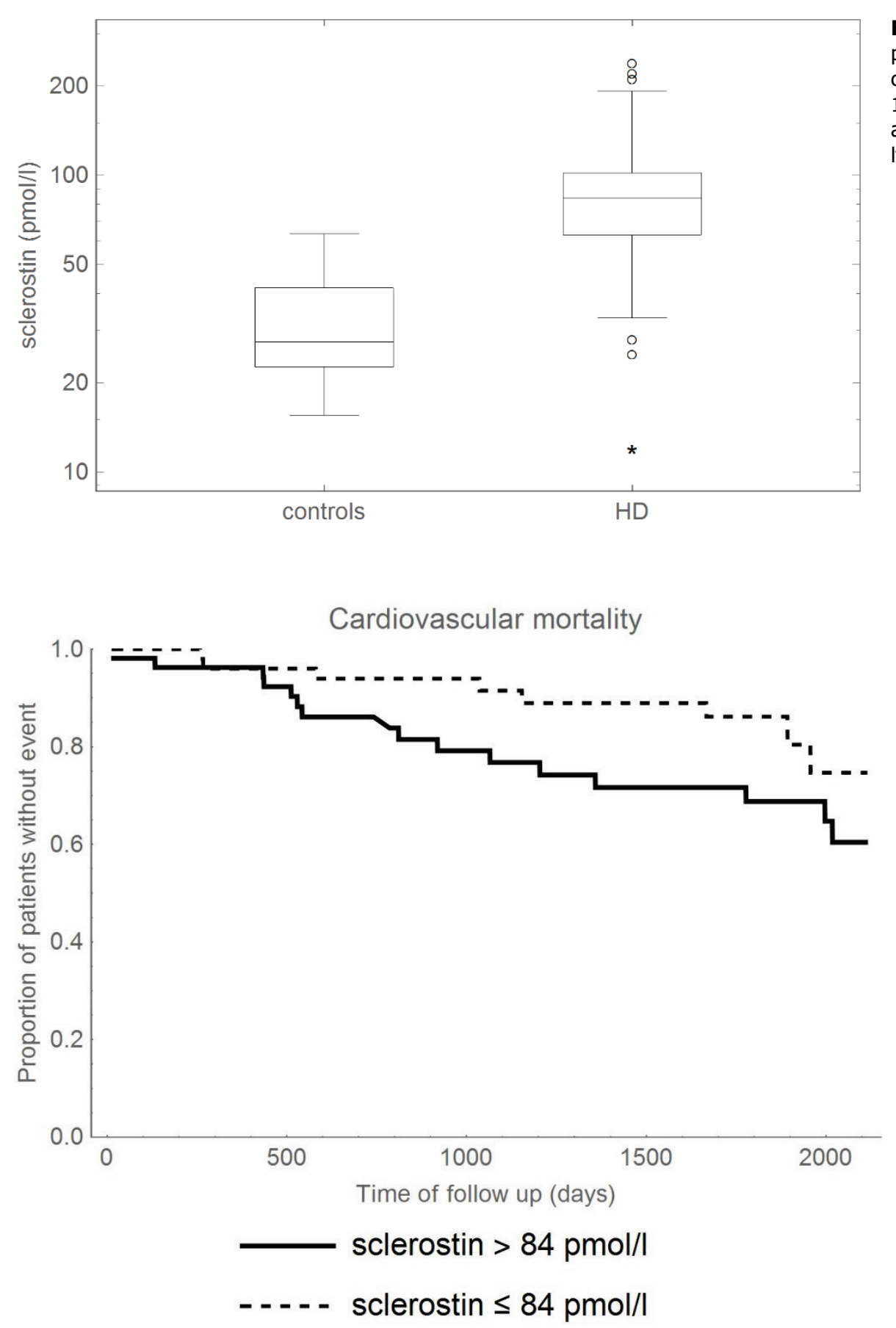

Fig. 1. Sclerostin in hemodialysis patients and healthy controls. HD vs. controls: $89.2 \pm 40.3 \mathrm{pmol} / \mathrm{l}, 32.8 \pm$ $13.0 \mathrm{pmol} / \mathrm{l}, \mathrm{p}<0.001, \mathrm{p}=0.029$ after adjustment for age. HD - hemodialysis.

Fig. 2. Kaplan-Meier analysis showing cardiovascular mortality of hemodialysis patients based on sclerostin levels: sclerostin below $(\leq 84 \mathrm{pmol} / \mathrm{l})$ and above median (>84 pmol/l). $\mathrm{p}=0.044$ (log-rank test) 


\section{Results}

Sclerostin concentrations in serum are almost three times higher in the HD patients when compared to the controls $(89.2 \pm 40.3 \mathrm{pmol} / 1$ vs. $32.8 \pm 13.0 \mathrm{pmol} / 1$, $\mathrm{p}<0.001, \mathrm{p}=0.029$ after adjustment for age, Fig. 1) and

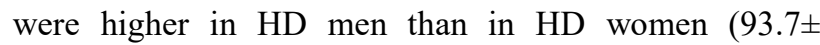
$38.6 \mathrm{pmol} / 1$ vs. $82.2 \pm 42.4 \mathrm{pmol} / \mathrm{l}, \mathrm{p}=0.019$ ). The results of other laboratory parameters are shown in Table 1.

In HD patients, sclerostin correlated with age ( $\tau=0.142, \mathrm{p}=0.034)$, creatinine $(\tau=0.224, \mathrm{p}=0.001)$, and calcium $(\tau=0.144, \quad \mathrm{p}=0.030)$, and was negatively correlated with cholesterol $(\tau=-0.131, \mathrm{p}=0.048)$ and alkaline phosphatase ( $\tau=-0.139, \mathrm{p}=0.035)$. In the controls, no significant correlation between the basic laboratory parameters and age was observed. There was no difference in sclerostin levels between diabetics and non-diabetics, between patients with and without cardiovascular, peripheral vascular or cerebrovascular diseases in their personal history, and there was no relationship with hypertension. Additionally, there was no difference of serum sclerostin concentrations among various primary renal diagnoses. Sclerostin was higher in anuric patients $(99.9 \pm 43.2 \mathrm{pmol} / \mathrm{l}$ vs. $78.0 \pm$ $34.3 \mathrm{pmol} / \mathrm{l}, \mathrm{p}=0.004)$ and correlated with residual diuresis ( $\tau=-0.203, p=0.005$ for all patients).

The Kaplan-Meier analysis did not find any significance of sclerostin for overall mortality and mortality due to infection but sclerostin levels were significant for cardiovascular mortality ( $\mathrm{p}=0.044$, Fig. 2 ). A higher cardiovascular risk was connected to sclerostin concentrations above the median ( $>84 \mathrm{pmol} / \mathrm{l})$. This was also confirmed using the Cox proportional hazard model giving HR (95\% CI) 2.577 (1.0002-10.207), $\mathrm{p}=0.04$. When sclerostin was evaluated together with residual diuresis in Kaplan-Meier analysis: the worst prognosis due to cardiovascular events was observed in the group with high sclerostin and zero residual diuresis in comparison to all of the other patients ( $\mathrm{p}=0.007$, Fig. 3). A similar result for sclerostin-anuria interaction also remained significant in the Cox model when sex, age, BMI and albumin were applied in the model, HR $(95 \%$ CI $) 3.251$ (1.094-9.663), $\mathrm{p}=0.034$. The same finding was also observed after further adjustment for comorbidities - diabetes mellitus, dyslipidemia and any pre-existing cardiac or vascular disease, HR $(95 \% \mathrm{CI})$ 7.864 (1.989-31.092), $\mathrm{p}=0.003$. Cox regression has not shown any significance for overall mortality and mortality due to infection.

In conclusion, sclerostin is elevated in HD patients and its higher concentrations (above the median concentrations in HD patients) are linked to higher cardiovascular mortality.

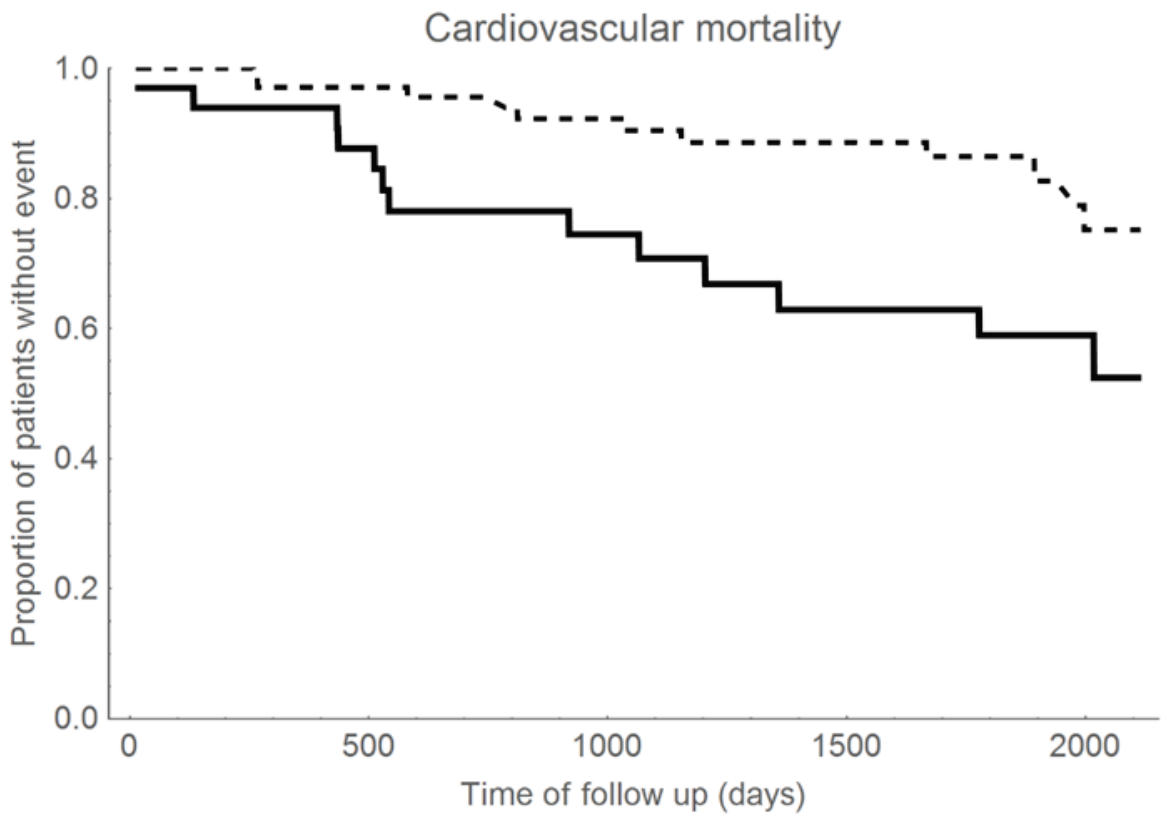

- sclerostin $>84 \mathrm{pmol} / \mathrm{l} \&$ anuria
Fig. 3. Kaplan-Meier analysis showing cardiovascular mortality of hemodialysis patients based on sclerostin levels and residual diuresis: sclerostin below ( $\leq 84 \mathrm{pmol} / \mathrm{l}$ ) and above median $(>84 \mathrm{pmol} / \mathrm{l})$ and residual diuresis $0 \mathrm{ml} / 24$ hours (anuria) and $>0 \mathrm{ml} /$ 24 hours. $p=0.007$ (log-rank test) 


\section{Discussion}

The present prospective observational cohort study shows that in long-term HD patients, the serum sclerostin levels are increased compared to healthy subjects. High levels of serum sclerostin were revealed as a risk factor for cardiovascular mortality.

In our study, serum sclerostin levels were three times higher in HD patients compared to subjects with normal kidney function, and were higher in males than in females similar to the results of another study by Sato et al. (Sato et. al. 2018). Higher cardiovascular risk was connected to sclerostin concentrations above the median. Furthermore, the worst prognosis due to cardiovascular events was even more pronounced in the group of anuric HD patients with high sclerostin levels than in all other groups of HD patients.

In various studies conducted on HD patients, different methods of serum sclerostin levels measurement of HD patients were used, and the results also differ. Not only were the absolute concentrations for sclerostin levels discrepant, but the significance of sclerostin for patients' prognosis also showed conflicting results.

Firstly, in the clinical-laboratory studies currently available to date, sclerostin has been measured immunochemically using ELISA kits by three different manufacturers (mainly Biomedica, TECO Medical, and recently also R\&D Systems) (Piec et al. 2016). Currently, a novel automated chemiluminescent sclerostin assay (LIAISON $®$, DiaSorin) has become available for research use (Drake et al. 2018). Several comparative studies have been performed and the results obtained from different assays differ (McNulty et al. 2011, Costa et al. 2014, Moysés et al. 2015, Mause et al. 2016, Piec et al. 2016), i.e. a standardization between the measurements of the serum sclerostin level in the HD population is required.

Secondly, the conflicting results evaluating a correlation between serum sclerostin levels and mortality may be linked to the variying lengths of the observational periods.

Finally, different age groups in heterogenous HD patients, their comorbid conditions and the duration of dialysis treatment are further plausible confounding factors.

Some studies of the HD population showed that serum sclerostin levels were significantly associated with overall mortality (Gonçalves et al. 2014, Kanbay et al. 2014, Gong et al. 2018, Novo-Rodríguez et al. 2018), whereas other studies demonstrated no association with overall mortality (Viaene et al. 2013, Jean et al. 2016, Drechsler et al. 2015, Lips et al. 2016, Delanaye et al. 2014, Nowak et al. 2015, Sato et al. 2018). The studies investigating sclerostin in cardiovascular disease (CVD) morbidity and mortality in HD populations are shown in Table 2.

Similarly to our study, sclerostin was demonstrated as an independent mortality predictor in $91 \mathrm{HD}$ patients who were followed up with for 10 years. In that study, sclerostin was determined using the TECO Medical assay (Gonçalves et al. 2014). Additionally, an association of sclerostin levels (Biomedica assay) with overall mortality as well as cardiovascular events was found in non-dialyzed chronic kidney disease patients (Kanbay et al. 2014). A recent prospective observational study of serum sclerostin concentrations assessed by enzyme immunoassay (Biomedica assay) in 98 peritoneal dialysis (PD) patients during the 6-year study period suggested that high levels of serum sclerostin were significantly linked to new-onset cardiovascular events and cardiovascular mortality (Gong et al. 2018). A study by Novo-Rodríguez et al. (Novo-Rodríguez et al. 2018) fully supports our results. These authors concluded that high sclerostin levels (measured using the Biomedica kit) are related to mortality due to cardiovascular causes (follow up 2007-2014), but no association was found between sclerostin and infectious (non-cardiovascular) causes of mortality in their cohort of 130 hemodialysis patients (75 patients with diabetes mellitus). An increase of serum sclerostin by $10 \mathrm{pmol} / 1$ resulted in a $31 \%$ increase in cardiovascular mortality. According to the authors, the clinical implication of these findings are based on the possible use of serum sclerostin as a new biomarker for cardiovascular mortality risk in order to establish preventive strategies. This is also in perfect agreement with our conclusion.

However, Viaene et al. (2013) assessed sclerostin using the Biomedica kit in 100 prevalent dialysis patients who were followed up with for 637 days, a much shorter period compared to our study and have shown that high circulating sclerostin levels are associated with improved survival. In addition, a crosssectional study of prevalent HD patients by Jean et al. (Jean et al. 2016) showed that higher serum sclerostin levels were linked to higher bone mineral density, lower Kupilla aortic calcification scores and a better survival rate. In the NECOSAD study performed with $673 \mathrm{HD}$ and PD patients (4-years follow up) where sclerostin was 
Table 2. Studies investigating sclerostin in CVD morbidity and mortality in HD

\begin{tabular}{|c|c|c|c|c|c|}
\hline Authors & $\begin{array}{l}\text { Method } \\
\text { (ELISA) }\end{array}$ & $\begin{array}{l}\text { Study } \\
\text { population }\end{array}$ & Study type & $\begin{array}{l}\text { Study } \\
\text { duration }\end{array}$ & Study outcomes \\
\hline $\begin{array}{l}\text { Kalousová et al. } \\
2019\end{array}$ & Biomedica & $\mathrm{HD}(\mathrm{n}=106)$ & $\begin{array}{l}\text { Prospective } \\
\text { observational }\end{array}$ & 5 years & $\begin{array}{l}\text { High sclerostin levels } \\
\text { were significant for } \\
\text { CVD mortality }\end{array}$ \\
\hline $\begin{array}{l}\text { Gonçalves et al. } \\
2014\end{array}$ & TECO Medical & $\mathrm{HD}(\mathrm{n}=91)$ & $\begin{array}{l}\text { Prospective } \\
\text { observational }\end{array}$ & 10 years & $\begin{array}{l}\text { High sclerostin was } \\
\text { associated with CVD } \\
\text { in prevalent HD } \\
\text { population }\end{array}$ \\
\hline $\begin{array}{l}\text { Kanbay et al. } \\
2014\end{array}$ & Biomedica & $\begin{array}{l}\text { CKD (3-5) } \\
(n=173)\end{array}$ & $\begin{array}{l}\text { Prospective } \\
\text { observational }\end{array}$ & 26 months & $\begin{array}{l}\text { High sclerostin levels } \\
\text { were associated with } \\
\text { CVD in non-dialyzed } \\
\text { CKD population }\end{array}$ \\
\hline $\begin{array}{l}\text { Viaene et al. } \\
2013\end{array}$ & Biomedica & $\operatorname{HD}(n=100)$ & $\begin{array}{l}\text { Post-hoc } \\
\text { survival analysis } \\
\text { in a cross } \\
\text { sectional study }\end{array}$ & 637 days & $\begin{array}{l}\text { High sclerostin levels } \\
\text { were associated with } \\
\text { improved survival in } \\
\text { prevalent HD patients }\end{array}$ \\
\hline $\begin{array}{l}\text { Drechsler et al. } \\
2016\end{array}$ & $\begin{array}{l}\text { TECO Medical } \\
\text { High sensitive }\end{array}$ & $\begin{array}{l}\text { HD and PD } \\
(\mathrm{n}=637) 90 \% \\
\text { prevalence of HD } \\
\text { patients } \\
\text { (NECOSAD } \\
\text { study) }\end{array}$ & $\begin{array}{l}\text { Observational } \\
\text { prospective } \\
\text { follow-up cohort } \\
\text { study }\end{array}$ & $\begin{array}{l}18 \text { months } \\
\text { and } 4 \text { years }\end{array}$ & $\begin{array}{l}\text { High serum sclerostin } \\
\text { levels were associated } \\
\text { with lower short-term } \\
\text { CVD and overall } \\
\text { mortality in HD } \\
\text { patients }\end{array}$ \\
\hline $\begin{array}{l}\text { Lips et al. } \\
2016\end{array}$ & Biomedica & $\begin{array}{l}\mathrm{HD}(\mathrm{n}=198) \text { and } \\
\text { HDF }(\mathrm{n}=198) \\
\text { (CONTRAST } \\
\text { study) }\end{array}$ & $\begin{array}{l}\text { Prospective } \\
\text { observational }\end{array}$ & 2.9 years & $\begin{array}{l}\text { High sclerostin levels } \\
\text { were associated with } \\
\text { lower mortality risk }\end{array}$ \\
\hline $\begin{array}{l}\text { Delanaye et al. } \\
2014\end{array}$ & TECO Medical & $\mathrm{HD}(\mathrm{n}=164)$ & $\begin{array}{l}\text { Prospective } \\
\text { observational }\end{array}$ & 2 years & $\begin{array}{l}\text { No association } \\
\text { between baseline } \\
\text { sclerostin } \\
\text { concentrations and } \\
\text { mortality }\end{array}$ \\
\hline $\begin{array}{l}\text { Nowak et al. } \\
2015\end{array}$ & TECO Medical & $\mathrm{HD}(\mathrm{n}=239)$ & $\begin{array}{l}\text { Multicentre } \\
\text { prospective } \\
\text { observational }\end{array}$ & 1461 days & $\begin{array}{l}\text { No association } \\
\text { between sclerostin and } \\
\text { all-cause mortality }\end{array}$ \\
\hline $\begin{array}{l}\text { Jean et al. } \\
2016\end{array}$ & $\begin{array}{l}\text { TECO Medical } \\
\text { High sensitive }\end{array}$ & $\mathrm{HD}(\mathrm{n}=207)$ & $\begin{array}{l}\text { Cross-sectional } \\
\text { prospective } \\
\text { observational }\end{array}$ & 30 months & $\begin{array}{l}\text { Higher serum } \\
\text { sclerostin levels were } \\
\text { associated with better } \\
\text { survival }\end{array}$ \\
\hline $\begin{array}{l}\text { Sato et al. } \\
2018\end{array}$ & Biomedica & $\operatorname{HD}(n=389)$ & $\begin{array}{l}\text { Prospective } \\
\text { observational } \\
\text { cohort study }\end{array}$ & 72 months & $\begin{array}{l}\text { Serum sclerostin was } \\
\text { not an independent } \\
\text { predictor in } \\
\text { maintenance HD } \\
\text { patients }\end{array}$ \\
\hline $\begin{array}{l}\text { Kanbay et al. } \\
2016\end{array}$ & Metanalysis & $\begin{array}{l}\text { HD }(n=1788) \\
9 \text { studies }\end{array}$ & & & $\begin{array}{l}\text { Serum sclerostin was } \\
\text { not associated with } \\
\text { overall and CVD } \\
\text { mortality }\end{array}$ \\
\hline
\end{tabular}


measured using the HS EIA kit TECO Medical, high levels of serum sclerostin were associated with lower cardiovascular mortality (mainly short-term mortality) in dialysis patients (Drechsler et al. 2015). However, statistically significant results were obtained only when HD and PD patients were evaluated together, while in separate categories of HD or PD patients, the trend was not significant. In a recent study of 396 HD patients with a median follow up of 2.9 years (CONTRAST study) (Biomedica assay) high serum sclerostin was associated with a lower mortality risk (Lips et al. 2016). Another study with 164 HD patients followed up for 2 years found no difference in the baseline concentrations of sclerostin (TECO Medical kit) in the survivors and non-survivors (Delanaye et al. 2014). Similarly, no significance of sclerostin for the mortality of HD patients (239 HD patients, 1461 days follow up, measurement of sclerostin using the TECO Medical kit) was described by Nowak et al. (2015). A study by Sato et al. in 2018 found no association between serum sclerostin (assessed by Biomedica assay) and (total) mortality in a cohort of 389 Japanese hemodialysis patients with 42 months of follow-up (Sato et al. 2018). A recent quantitative meta-analysis of 9 studies of CKD patients (1788 patients included in total) revealed no relationship between serum sclerostin concentrations and either overall or cardiovascular mortality (Kanbay et al. 2016).

Similarly, studies focusing on sclerostin in vascular calcifications in end-stage renal disease do not yeild the same results. For example, Yang et al. reported an inverse correlation between sclerostin and aortic calcification scoring (calculated from plain X ray films of both posterior-anterior and lateral views) and future cardiovascular events (Yang et al. 2015). Similarly, other studies (Delanaye et al. 2014, Evenepoel et al. 2015, Lee et al. 2016, Sato et al. 2018) have shown the connections between elevated sclerostin levels and a lower prevalence and severity of vascular calcifications. Most probably, sclerostin may restrain the progression of vessel calcification by a similar mechanism of antagonising bone formation.

However, in the study by Quereshi et al. (2015) the increased sclerostin levels were described as a positive predictor of vascular calcifications. High serum sclerostin was associated with coronary artery calcification evaluated by $\mathrm{CT}$ as well as with biopsy verified epigastric artery calcification (Qureshi et al. 2015). The cross-sectional study by Morena et al. in 2015 found that bone turnover inhibitors, sclerostin and osteoprotegerin, specifically their high serum levels, were independently correlated with coronary artery calcifications with potential additive impact in 241 non-dialyzed chronic kidney disease (non-HD CKD) patients, in the context of low to normal PTH levels (Morena et al. 2015). These findings further emphasize the conclusion that verified optimal values for PTH, osteoprotegerin and sclerostin should be established in the HD and non-HD CKD population with the goal of preventing vascular calcifications. Paradoxically the positive association between high sclerostin levels and vascular calcifications might be due to the inhibitory effect of sclerostin, counterbalancing other mechanisms involved in vessel calcifications.

Sclerostin levels behave differently in acute settings like critical illness. For example, in the study by Koch et al. sclerostin levels were significantly increased in critically ill patients, but were not a predictor of mortality (Koch et al. 2017). Sclerostin serum levels were not different in terms of the gender or age of critically ill patients. Sclerostin concentrations were associated with disease severity and independent on the presence of sepsis. Pre-existing kidney, or liver impairment, abnormalities of bone metabolism, but not cardiovascular disease were major influencing factors on the circulating sclerostin concentrations in the critically ill patients (Koch et al. 2017).

Interestingly, a recent study by Cejka et al. (2014) concluded that the increasing levels of sclerostin in patients with a progressive decline of kidney function occur not because of the renal sclerostin retention, but because of the increased production of sclerostin by osteocytes (Cejka et al. 2014).

Given the knowledge that inactivating mutations of SOST, the gene for sclerostin, leads to formation of strong dense bones, there are emerging novel treatment strategies against sclerostin which stimulate bone formation and decrease bone resorption. Trials using romosozumab have now reached phase I and II (McClung et al. 2014, Padhi et al. 2014). Romosozumab is a humanized monoclonal antibody that targets sclerostin. A clinical trial (phase III) on the treatment of osteoporosis using romosozumab was performed on 7180 postmenopausal women without renal failure. The trial demonstrated decreased risk of vertebral fracture after 12 months in the group treated with romosozumab, while adverse events including cardiovascular ones, were comparable between the treated and non-treated groups (Cosman et al. 2016). These promising results in treating 
osteoporosis with anti-sclerostin antibody might be of value as an aid in developing strategies beneficiary for both bone health and vascular calcifications in patients with kidney disease, as well as possibly improving the survival in HD population.

Treatment of HD patients with hemodiafiltration (CONTRAST study) lead to a decrease of serum sclerostin levels, and this decline was dependent on the magnitude of convection volume (Lips et al. 2016). However, the possible removal of sclerostin during a single dialysis procedure with a high-flux membrane does not explain the decrease in sclerostin levels in the long-term. Additionally, the secondary analysis of the CONTRAST study also demonstrated an association between high sclerostin levels and a lower mortality risk. A study by Carlson et al. found that the clearance of sclerostin during hemodialysis occurs at a lower rate but intradialytic plasma levels of substrates involved in bone metabolism including sclerostin remains largely unchanged (Carlson et al. 2017). The role of sclerostin as the mediator between bone and vasculature in chronic disease - mineral bone disorder (CKD-MBD) remains a fascinating analytical and clinical area for future further investigations.

Our present study had some limitations. Firstly, the study was observational and some unknown confounding factors might not have been considered when interpreting the results. However, we performed a profound statistical analysis, which was identified and adjusted for relevant variables. Secondly, the study evaluated only a moderate sample of the HD population of two hemodialysis centres, although the proportion of the deceased HD patients due to infectious or cardiovascular causes still allowed us to perform the mortality analysis.

We can summarize that sclerostin seems to be a potentially significant biomarker in patients with chronic kidney disease treated with long-term hemodialysis. High levels of serum sclerostin were revealed as a risk factor for cardiovascular mortality in long-term HD patients. However, for the proper usage of sclerostin in clinical practice we would need comparable laboratory methods, randomized controlled trials, a better understanding of bone turnover as well as of detailed mechanisms of vascular and extraosseal calcifications. Based on this novel information we could discuss the possible therapeutic measures to influence sclerostin and explore the significance of mortality risk in those patients with chronic kidney disease treated by hemodialysis.

\section{Conflict of Interest}

The authors declare that they have no conflict of interest.

\section{Acknowledgements}

The study was supported by research projects Progres Q25/LF1/2 and Q40/group14 and MH CZ DRO VFN 64165. The authors are thankful to the physicians and nurses from dialysis centers as well as to the laboratory staff for their technical assistance.

\section{References}

AMREIN K, AMREIN S, DREXLER C, DIMAI HP, DOBNIG, PFEIFER K, TOMASCHITZ A, PIEBER TR, FAHRLEITNER-PAMMER A: Sclerostin and its association with physical activity, age, gender, body composition, and bone mineral content in healthy adults. J Clin Endocrinol Metab 97: 148-154, 2012.

BALEMANS W, PATEL N, EBELING M, VAN HUL E, WUYTS W, LACZA C, DIOSZEGI M, DIKKERS FG, HILDERING P, WILLEMS PJ, VERHEIIJ, JB, LINDPAINTNER K, VICKERY B, FOERNZLER D, VAN HUL W: Identification of a $52 \mathrm{~kb}$ deletion downstream of the SOST gene in patients with van Buchem disease. J Med Genet 39: 91-97, 2002.

BALEMANS W, EBELING M, PATEL N, VAN HUL E, OLSON P, DIOSZEGI M, LACZA C, WUYTS W, VAN DEN ENDE J, WILLEMS P, PAES-ALVES AF, HILL S, BUENO M, RAMOS FJ, TACCONI P, DIKKERS FG, STRATAKIS C, LINDPAINTER K, VICKERY B, FOERNZLER D, VAN HUL W: Increased bone density in sclerosteosis is due to the deficiency of a novel secreted protein (SOST). Hum Mol Genet 10: 537-543, 2001.

BRANDENBURG VM, D'HAESE P, DECK A, MEKAHLI D, MEIJERS B, NEVEN E, EVENEPOEL P: From skeletal to cardiovascular disease in 12 steps-the evolution of sclerostin as a major player in CKD-MBD. Pediatr Nephrol 31: 195-206, 2016.

BRANDENBURG VM, KRAMANN R, KOOS R, KRÜGER T, SCHURGERS L, MÜHLENBRUCH G, HÜBNER S, GLADZIWA U, DRECHSLER C, KETTELER M: Relationship between sclerostin and cardiovascular calcification in hemodialysis patients: a cross-sectional study. BMC Nephrol 14: 219, 2013. 
BRUNKOW ME, GARDNER JC, VAN NESS J, PAEPER BW, KOVACEVICH BR, PROLL S, SKONIER JE, ZHAO L, SABO PJ, FU, Y, ALISCH RS, GILLETT L, COLBERT T, TACCONI P, GALAS D, HAMERSMA H, BEIGHTON P, MULLIGAN J: Bone dysplasia sclerosteosis results from loss of the SOST gene product, a novel cystine knot-containing protein. Am J Hum Genet 68: 577-589, 2001.

CARLSON N, MORTENSEN OH, AXELSEN M, PEDERSEN RS, HEAF JG: Clearance of sclerostin, osteocalcin, fibroblast growth factor 23, and osteoprotegerin by dialysis. Blood Purif 44: 122-128, 2017.

CEJKA D, HERBERTH J, BRANSCUM AJ, FARDO DW, MONIERFAUGERE MC, DIARRA D, HAAS M, MALLUCHE HH: Sclerostin and Dickkopf-1 in renal osteodystrophy. Clin J Am Soc Nephrol 6: 877-882, 2011.

CEJKA D, MARCUlESCU R, KOZAKOWSKI N, PLISCHKE M, REITER T, GESSL A, HAAS M: Renal elimination of sclerostin increases with declining kidney function. J Clin Endocrinol Metab 99: 248-255, 2014.

COSMAN F, CRITTENDEN DB, ADACHI JD, BINKLEY N, CZERWINSKI E, FERRARI S, HOFBAUER LC, LAU E, LEWIECKI EM, MIYAUCHI A, ZERBINI CA, MILMONT CE, CHEN L, MADDOX J, MEISNER PD, LIBANATI C, GRAUER A: Romosozumab treatment in postmenopausal women with osteoporosis. N Engl J Med 375: 1532-1543, 2016.

COSTA AG, CREMERS S, DWORAKOWSKI E, LAZARETTI-CASTRO M, BILEZIKIAN JP: Comparison of two commercially available ELISAs for circulating sclerostin. Osteoporos Int 25: 1547-1554, 2014.

DALLAS SL, PRIDEAUX M, BONEWALD LF: The osteocyte: an endocrine cell... and more. Endocr Rev 34: 658-690, 2013.

DELANAYE P, KRZESINSKI JM, WARLING X, MOONEN M, SMELTEN N, MÉDART L, BRUYĖRE O, REGINSTER JY, POTTEL H, CAVALIER E: Clinical and biological determinants of sclerostin plasma concentration in hemodialysis patients. Nephron Clin Pract 128: 127-134, 2014.

DRAKE MT, FENSKE JS, BLOCKI FA, ZIEROLD C, APPELMAN-DIJKSTRA N, PAPAPOULOS S, KHOSLA S: Validation of a novel, rapid, high precision sclerostin assay not confounded by sclerostin fragments. Bone 111: 36-43, 2018.

DRECHSLER C, EVENEPOEL P, VERVLOET MG, WANNER C, KETTELER M, MARX N, FLOEGE J, DEKKER FW, BRANDENBURG VM, GROUP NS: High levels of circulating sclerostin are associated with better cardiovascular survival in incident dialysis patients: results from the NECOSAD study. Nephrol Dial Transplant 30: 288-293, 2015.

EVENEPOEL P, GOFFIN E, MEIJERS B, KANAAN N, BAMMENS B, COCHE E, CLAES K, JADOUL M: Sclerostin serum levels and vascular calcification progresssion in prevalent renal transplant recipients. $J C l i n$ Endocrinol Metab 100: 4669-4679, 2015.

GONG L, ZHENG D, YUAN J, CAO L, NI Z, FANG W: Elevated levels of serum sclerostin are linked to adverse cardiovascular outcomes in peritoneal dialysis patients. Int Urol Nephrol 50: 955-961, 2018.

GONÇALVES FL, ELIAS RM, DOS REIS LM, GRACIOLLI FG, ZAMPIERI FG, OLIVEIRA RB, JORGETTI V, MOYSÉS RM: Serum sclerostin is an independent predictor of mortality in hemodialysis patients. $B M C$ Nephrol 15: 190, 2014.

JEAN G, CHAZOT C, BRESSON E, ZAOUI E, CAVALIER E: High serum sclerostin levels are associated with a better outcome in hemodialysis patients. Nephron 132: 181-90, 2016.

KALOUSOVA M, DUSILOVA-SULKOVA S, ZAKIYANOV O, KOSTIROVA M, SAFRANEK R, TESAR V, ZIMA $\mathrm{T}$ : Vitamin D binding protein is not involved in vitamin D deficiency in patients with chronic kidney disease. Biomed Res Int 2015: 492365, 2015.

KALOUSOVÁ M, JÁCHYMOVÁ M, MURAVSKÁ A, KUBĚNA AA, DUSILOVA-SULKOVÁ S, TESAŘ V, ZIMA $\mathrm{T}$ : Cys327Cys polymorphism of the PAPP-A gene (pregnancy associated plasma protein A) is related to mortality of long term hemodialysis patients. Clin Biochem 47: 578-83, 2014.

KALOUSOVÁ M, DUSILOVÁ-SULKOVÁ S, KUBĚNA AA, ZAKIYANOV O, LEVOVÁ K, BOCKOVÁ M, GEDEONOVÁ E, SONG XC, ERMINI ML, ŠPRINGER T, HOMOLA J, TESAŘ V, ZIMA T: Pregnancyassociated plasma protein A2 in hemodialysis patients: significance for prognosis. Kidney Blood Press Res 42 : 509-518, 2017. 
KANBAY M, SOLAK Y, SIRIOPOL D, ASLAN G, AFSAR B, YAZICI, D, COVIC A: Sclerostin, cardiovascular disease and mortality: a systematic review and meta-analysis. Int Urol Nephrol 48: 2029-2042, 2016.

KANBAY, M, SIRIOPOL D, SAGLAM M, KURT YG, GOK M, CETINKAYA H, KARAMAN M, UNAL HU, OGUZ Y, SARI S, EYILETEN T, GOLDSMITH D, VURAL A, VEISA G, COVIC A, YILMAZ MI: Serum sclerostin and adverse outcomes in nondialyzed chronic kidney disease patients. J Clin Endocrinol Metab 99: E1854-1861, 2014.

KOCH A, WEISKIRCHEN R, LUDWIG S, BUENDGENS L, BRUENSING J, YAGMUR E, BAECK C, HERBERS U, TRAUTWEIN C, TACKE F: Relevance of serum sclerostin concentrations in critically ill patients. $J$ Crit Care 37: 38-44, 2017.

LEE YT, NG HY, CHIU TT, LI CC, PEI SN, KU WH, LEE CT: Association of bone-derived biomarkers with vascular calcification in chronic hemodialysis patients. Clin Chim Acta 452: 38-43, 2016.

LIPS L, DE ROIJ VAN ZUIJDEWIJN CL, TER WEE PM, BOTS ML, BLANKESTIJN PJ, VAN DEN DORPEL MA, FOUQUE D, DE JONGH R, PELLETIER S, VERVLOET MG, NUBE MJ, GROOTEMAN MP: Serum sclerostin: relation with mortality and impact of hemodiafiltration. Nephrol Dial Transplant 32: 1217-1223, 2016.

MAUSE SF, DECK A, HENNIES M, KAESLER N, EVENEPOEL P, BOISVERT WA, JANSSEN U, BRANDENBURG VM: Validation of commercially available ELISAs for the detection of circulating sclerostin in hemodialysis patients. Discoveries (Craiova) 4: e55, 2016.

MCNULTY M, SINGH RJ, LI X, BERGSTRALH EJ, KUMAR R: Determination of serum and plasma sclerostin concentrations by enzyme-linked immunoassays. J Clin Endocrinol Metab 96: E1159-1162, 2011.

MCCLUNG MR, GRAUER A, BOONEN S, BOLOGNESE MA, BROWN JP, DIEZ-PEREZ A, LANGDAHL BL, REGINSTER, JY, ZANCHETTA JR, WASSERMAN SM, KATZ L, MADDOX J, YANG YCH, LIBANATI C, BONE HG: Romosozumab in postmenopausal with low bone mineral density. $N$ Engl J Med 370: 412-420, 2014.

MOYSÉS RM, JAMAL SA, GRACIOLLI FG, DOS REIS LM, ELIAS RM: Can we compare serum sclerostin results obtained with different assays in hemodialysis patients? Int Urol Nephrol 47: 847-850, 2015.

MÖDDER UI, HOEY KA, AMIN S, MCCREADY LK, ACHENBACH SJ, RIGGS BL, MELTON, LJ, KHOSLA S: Relation of age, gender, and bone mass to circulating sclerostin levels in women and men. $J$ Bone Miner Res 26: 373-379, 2011.

MORENA M, JAUSSENT I, DUPUY AM, KUSTER N, CHENINE L, LERAY-MORAQUES H, KLOUCHE K, VEMHET H, CANAUD B, CRISTOL JP: Osteoprotegerin and sclerostin in chronic kidney disease prior do dialysis: potential partners in vascualr calcifications. Nephrol Dial Transplant 34: 1345-1356, 2015.

NOWAK A, ARTUNC F, SERRA, AL, POLLOCK E, KRAYENBÜHL PA, MÜLLER C, FRIEDRICH B: Sclerostin quo vadis? - is this a useful long-term mortality parameter in prevalent hemodialysis patients? Kidney Blood Press Res 40: 266-276, 2015.

OTT SM: Bone cells, sclerostin, and FGF23: what's bred in the bone will come out in the flesh. Kidney Int 87: 499-501, 2015.

PADHI D, ALLISON M, KIVITZ AJ, GUTIERREZ MJ, STOUCH B, WANG C, JANG G: Multiple doses of sclerostin antibody romosozumab in healthy men and postmenopausal women with low bone mass: a randomized double blind, placebo-controlled study. J Clin Pharmacol 54: 168-178, 2014.

PELLETIER S, DUBOURG L, CARLIER MC, HADJ-AISSA A, FOUQUE D: The relation between renal function and serum sclerostin in adult patients with CKD. Clin J Am Soc Nephrol 8: 819-823, 2013.

PELLETIER S, CONFAVREUX CB, HAESEBAERT J, GUEBRE-EGZIABHER F, BACCHETTA J, CARLIER MC, CHARDON L, LAVILLE M, CHAPURLAT R, LONDON GM, LAFAGE-PROUST MH, FOUQUE D: Serum sclerostin: the missing link in the bone-vessel cross-talk in hemodialysis patients? Osteoporos Int 26: 2165-2174, 2015.

PIEC I, WASHBOURNE C, TANG J, FISHER E, GREEVES J, JACKSON S, FRASER WD: How accurate is your sclerostin measurement? Comparison between three commercially available sclerostin ELISA kits. Calcif Tissue Int 98: 546-555, 2016. 
POOLE KE, VAN BEZOOIJEN RL, LOVERIDGE N, HAMERSMA H, PAPAPOULOS SE, LÖWIK CW, REEVE J: Sclerostin is a delayed secreted product of osteocytes that inhibits bone formation. FASEB J 19: 1842-1844, 2005.

QURESHI AR, OLAUSON H, WITASP A, HAARHAUS M, BRANDENBURG V, WERNERSON A, LINDHOLM B, SÖDERBERG M, WENNBERG L, NORDFOR SL, RIPSWEDEN J, BARANY P, STENVINKEL P: Increased circulating sclerostin levels in end-stage renal disease predict biopsy-verified vascular medial calcification and coronary artery calcification. Kidney Int 88: 1356-1364, 2015.

SATO M, HANAFUSA N, KAWAGUCHI H, TSUCHIYA K, NITTA K: A prospective cohort study showing no association between serum sclerostin level and mortality in maintenance hemodialysis patients. Kidney Blood Press Res 43: 1023-1033, 2018.

TERPOS, E, CHRISTOULAS D, KATODRITOU E, BRATENGEIER, C, GKOTZAMANIDOU M, MICHALIS E, DELIMPASI S, POULI A, MELETIS J, KASTRITIS E, ZERVAS K, DIMOPOULOS MA: Elevated circulating sclerostin correlates with advanced disease features and abnormal bone remodeling in symptomatic myeloma: reduction post-bortezomib monotherapy. Int J Cancer 131: 1466-1471, 2012.

THAMBIAH S, ROPLEKARR, MANGHAT P, FOGELMAN I, FRASER WD, GOLDSMITH D, HAMPSON G: Circulating sclerostin and Dickkopf-1 (DKK1) in predialysis chronic kidney disease (CKD): relationship with bone density and arterial stiffness. Calcif Tissue Int 90: 473-480, 2012.

VAN BEZOOIJEN RL, SVENSSON JP, EEFTING D, VISSER A, VAN DER HORST G, KARPERIEN M, QUAX PH, VRIELING H, PAPAPOULOS SE, TEN DIJKE P, LÖWIK CW: Wnt but not BMP signaling is involved in the inhibitory action of sclerostin on BMP-stimulated bone formation. J Bone Miner Res 22: 19-28, 2007.

VIAENE L, BEHETS GJ, CLAES K, MEIJERS B, BLOCKI F, BRANDENBURG V, EVENEPOEL P, D'HAESE PC: Sclerostin: another bone-related protein related to all-cause mortality in hemodialysis? Nephrol Dial Transplant 28: 3024-3030, 2013.

YANG CY, CHANG ZF, CHAU YP, CHEN A, YANG WC, YANG AH, LEE OK: Circulating Wnt/ $\beta$-catenin signalling inhibitors and uraemic vascular calcifications. Nephrol Dial Transplant 30: 1356-1363, 2015.

YAVROPOULOU MP, VAN LEROP AH, HAMDY NA, RIZZOLI R, PAPAPOULOS SE: Serum sclerostin levels in Paget's disease and prostate cancer with bone metastases with a wide range of bone turnover. Bone 51: 153-157, 2012.

ZENG C, GUO C, CAI J, TANG C, DONG Z: Serum sclerostin in vascular calcification and clinical outcome in chronic kidney disease. Diab Vasc Dis Res 15: 99-105, 2018.

ZHU D, MACKENZIE NC, MILLÁN JL, FARQUHARSON C, MACRAE VE: The appearance and modulation of osteocyte marker expression during calcification of vascular smooth muscle cells. PLoS One 6: e19595, 2011. 